\title{
DO THE EFFECTS OF VITAMIN D SUPPLEMENTATION ON MUSCLE STRENGTH DIFFER ACCORDING TO AGE?
}

Turkish Journal of Geriatrics DOI: $10.31086 /$ tjgeri.2018.58 2018;21 (4):529-535

- Gülsüm DOĞAN ${ }^{1}$

- Naciye Füsun TORAMAN ${ }^{2}$

- Neşe TOKTAŞ3

- Meral BiLGiLisoY FiLiz²

- Tuncay ÇAKIR ${ }^{4}$

- Şebnem KOLDAŞ DOĞAN²

- Tülay ERÇALIK ${ }^{5}$

\section{CORRESPONDANCE}

\section{Gülsüm DOĞAN}

Pamukkale University, Faculty of Medicine,

Department of Physical Medicine and

Rehabilitation, Division of Rheumatology

(formerly), Denizli, Turkey

Phone: 2422372283

e-mail: drgulsum07@gmail.com

Received: 29/08/2018

Accepted: 02/10/2018

${ }^{1}$ Pamukkale University, Faculty of Medicine,

Department of Physical Medicine and

Rehabilitation, Division of Rheumatology

(formerly), Denizli, Turkey

${ }^{2}$ Health Sciences University, Antalya Training

and Research Hospital, Physical Medicine and

Rehabilitation Clinic, Antalya, Turkey

${ }^{3}$ Akdeniz University, Faculty of Sport Sciences,

Antalya, Turkey

${ }^{4}$ Antalya Likya Hospital, Physical Medicine and

Rehabilitation Clinic, Antalya, Turkey

${ }^{5}$ Şişli Etfal Training and Research Hospital,

Physical Medicine and Rehabilitation Clinic,

Division of Algologia, İstanbul, Turkey

\section{Abstract}

Introduction: Vitamin D plays an important role in musculoskeletal health and its use improves muscle strength. However, the effect of vitamin D use on muscle strength in women of different ages is yet to be investigated. Therefore, in this study, we aimed to evaluate the effect of vitamin D use on muscle strength in women of different age groups and determine the differences of muscle strength gain between age groups.

Materials and Method: Sixty-three women with calcidiol levels $<30 \mathrm{ng} / \mathrm{mL}$ were randomly assigned and stratified by their age group as follows: Group I (aged 40-49 years), Group II (aged 50-59 years) and Group III (aged 60-69 years). Calcidiol levels, body mass index, fat free mass, percent fat, grip strength, arm curl, chair stand and isokinetic concentric flexor and extensor peak torque and power at $60^{\circ} \cdot \mathrm{s}-1$ and $180^{\circ} \cdot \mathrm{s}-1$ were assessed at baseline and six months after oral cholecalciferol supplementation.

Results: Vitamin D supplementation caused significant improvement in body mass index, arm curl, grip strength and knee flexor and extensor peak torque and power at $60^{\circ} \cdot 5-1$ and $180^{\circ} \cdot s-1$ in all groups $(p<0.05)$. Knee flexor power at $60^{\circ} \cdot s-1$ and extensor power at $180^{\circ} \cdot s-1$ were significantly higher in group I than in group III $(p<0.025)$.

Conclusion: Muscle strength in response to vitamin D supplementation increased in all age groups, and isokinetic muscle power was the highest in the youngest age group studied.

Keywords: Body composition; Muscle strength; Vitamin D; Women
ARAŞTIRMA

\section{VITAMININ KULLANIMININ KAS KUVVETINE ETKISI YAŞA GÖRE DEĞişiR Mi?}

\section{$\ddot{O ̈ z}$}

Giriş: D vitamininin muskuloskeletal sağlık için önemli olduğu ve D vitamin kullanımının kas kuvvetini arttırdığı bilinmektedir. Ancak, farklı yaşlardaki kadınlarda, D vitamin kullanımının kas kuvvetine etki farklıı̆ıını araştıran çalışma yoktur. Bu nedenle bu çalışmada, farkı yaş gruplarındaki kadınlarda D vitamin kullanımının kas kuvvetine etkisini değerlendirmek ve yaş grupları arasındaki kuvvet değişim farkını belirlemek amaçlanmıştır.

Gereç ve Yöntem: Kalsidiol düzeyi $<30 \mathrm{ng} / \mathrm{ml}$ olan altmış üç kadın rasgele olarak yaş gruplarına göre sınıflandııılı ve tabakalandı: Grup I (40-49 yaş arasında), Grup II (50-59 yaş arasında), ve Group III (60-69 yaş arasında). Kalsidiol düzeyi, beden kütle indeksi, yağsız kütle, yüzde yağ, kavrama kuvveti, kol bükme, otur kalk testleri ile 600.s-1 and 1800.s-1 hızlarda izokinetik konsantrik fleksör ve ekstensör zirve tork ve güç başlangıçta ve oral kolekalsifereol verildikten altı ay sonra değerlendirildi.

Bulgular: D vitamin kullanımı tüm yaş gruplarında beden kütle indeksi, kol bükme, kavrama kuvveti, $600 . s-1$ and 1800.s-1 hızlarda diz fleksör ve ekstensör zirve tork ve güçte artışa neden oldu ( $p<0.05)$. Grup I'de, Grup III'e kıyasla 600.s-1 hızda fleksör güç ve 1800.s-1 hızda ekstensör güç daha büyüktü $(p<0.025)$.

Sonuç: D vitamin kullanımı sonucu tüm yaş gruplarında kas kuvveti arttı ve izokinetik kas gücü artışının genç yaş grubunda daha fazla olduğu belirlendi.

Anahtar sözcükler: Beden kompozisyonu, Kas kuvveti, Vitamin D, Kadın 


\section{INTRODUCTION}

Muscle strength declines with age, and its loss is prominent in people over 40 years of age (1). Vitamin $D$ has a small but positive effect on muscle strength (2), and the improvement of muscle strength with vitamin D supplementation can only be achieved in persons with vitamin $\mathrm{D}$ deficiency (3). On performing meta-analysis, no significant effect of vitamin D supplementation was noted on grip strength in adults with $25(\mathrm{OH}) \mathrm{D}$ levels $>10 \mathrm{ng} / \mathrm{mL}$, but a large effect was noted on hip muscle strength in adults with $25(\mathrm{OH}) \mathrm{D}$ levels $<10 \mathrm{ng} / \mathrm{mL}$ (4). Most of the improvement in lower extremity functions occurred in 25(OH)D concentrations between 9 and $16 \mathrm{ng} /$ $\mathrm{mL}$, while the change was not as noticeable in the range of $16-37.6 \mathrm{ng} / \mathrm{mL}$ in older adults (5). In adults aged 65-102 years, vitamin 25(OH)D levels $<10$ $\mathrm{ng} / \mathrm{mL}$ were significantly associated with lower extremity performances, whereas serum 25(OH)D levels $<20 \mathrm{ng} / \mathrm{mL}$ were significantly associated with grip strength $(5,6)$. To the best of our knowledge, there is no study comparing the effects of serum $25(\mathrm{OH}) \mathrm{D}$ levels on muscle strength and that of vitamin $D$ supplementation on muscle strength gain across different age groups of women.

Some studies suggest that vitamin D improves isometric (7-11) or isokinetic muscle strength $(7,12,13)$, while other studies suggest that it has no effect on isometric $(12,14-16)$ and isokinetic muscle strength (17). However, no study has yet investigated the differences in isometric or isokinetic strength gain on vitamin $D$ supplementation in different age groups of women. Therefore, this study was designed to determine the effects of vitamin D supplementation on isometric and isokinetic muscle strength and to assess whether these effects differ according to the ages of women.

\section{MATERIALS AND METHOD}

Sixty-three sedentary women (aged 40-69 years) with $25(\mathrm{OH}) \mathrm{D}$ levels $<30 \mathrm{ng} / \mathrm{mL}$ and without a history of vitamin $D$ use within the last six months participated in the study and provided written informed consent. Exclusion criteria included the presence of any of the following comorbidities that may affect vitamin D levels or physical performance: renal and liver diseases, endocrine and neurologic diseases, a history of myocardial disease within the last six months, gastrointestinal malabsorption, the use of medicines which may affect muscles and the history of trauma/surgery of related muscles. The patients were stratified into the following three age groups: Group I (40-49 years of age), Group II (5059 years of age) and Group III (60-69 years of age).

Vitamin D supplementation with 300.000 IU oral cholecalciferol was administered to patients according to their vitamin D status in March 2013: three doses at 10-day intervals in patients with vitamin $D$ levels $\leq 10 \mathrm{ng} / \mathrm{mL}$, two doses at 15day intervals in patients with vitamin $D$ levels of $11-20 \mathrm{ng} / \mathrm{mL}$ and a single dose in patients with vitamin $D$ levels of $21-30 \mathrm{ng} / \mathrm{mL}$. Oral calcium supplementation was administered to patients with insufficient calcium intake to achieve a total daily calcium intake of $1000 \mathrm{mg}$. This study was approved by the Institutional Ethics Committee (decision no;date.4/5; 2012).

All the following outcome measures were assessed at baseline and on the sixth month following vitamin $D$ supplementation.

Serum 25(OH)D (calcidiol) assays (DiaSorin, Stillwater, MN, USA) were performed using direct competitive chemiluminescence immunoassay. LIAISON assay is linear up to $125 \mathrm{ng} / \mathrm{mL}$, the limit of detection is $3.5 \mathrm{ng} / \mathrm{mL}$ and the coefficient of variation ranges between $4.8 \%$ and $11.1 \%$. Blood samples were obtained after overnight fasting. Serum samples were separated via centrifugation at 3000 rpm for 10 minutes, and serum portions were stored at $-80^{\circ} \mathrm{C}$ and later used for analysing $25(\mathrm{OH})$ $D$ levels.

Height was measured using a tape measure with the participant in standing position. Body Mass Index (BMI), fat free mass (FFM) and percentage 
body fat were measured using Tanita Body Composition Analyzer (TANITA MC-180MA).

The handgrip strength of the dominant limb was measured using a baseline hydraulic hand dynamometer in which the dynamometer was used with participants in seated positions, their elbow by their side and flexed to right angles and their wrists in neutral positions. For the analyses, the maximum force from the three trials was used.

The chair stand test assessed lower body strength. The score was the total number of stands correctly executed within 30 seconds. The dominant side of the arm curl test assessed upper body strength. The score was the total number of hand weight curls through the full range of motion in 30 seconds (18). Isokinetic concentric measurements of knee flexor/extensor muscles at $60^{\circ} \cdot \mathrm{s}^{-1}$ and $180^{\circ} \cdot \mathrm{s}^{-1}$ were evaluated using ISOMED2000 (model code 106-012, Hemau/Germany/2008). The test protocol included five maximal contractions at each speed with 1-minute intervals between each speed. The relative peak torque and power values were used in the analysis.

The study participants were assessed for any adverse reactions of vitamin $D$ supplementation during and at the end of the study.

\section{Statistical analysis}

Data were analysed using the SPSS software (version 18.0). One-way ANOVA test was used for comparing baseline values and the post-hoc Tukey test was used. The level of significance was set at 0.05 . Multiple $3 \times 2$ (group $\times$ time) repeated measures ANOVA were performed for identifying significant changes over time. When significant differences were observed between groups at the start of the study, analysis of covariance was performed on the outcome variables at the end of the study. The covariate was the baseline value of each participant for the particular outcome variable being analysed. Post-hoc analyses were conducted using the Bonferroni test for examining time and group effects. The level of significance was set at 0.025; that is, 0.05 divided by 2 .

\section{RESULTS}

In the present study, we included 20 patients in the group I, 24 patients in the group II and 19 patients in the group III. One patient was excluded after stratification because of a haemorrhagic stroke. Vitamin D treatment was not associated with any clinically adverse reactions. Laboratory results revealed that serum $25(\mathrm{OH}) \mathrm{D}$ levels were $<10 \mathrm{ng} /$ $\mathrm{mL}$ in $95 \%$ of participants in groups I and III and in 92\% of participants in the group II. At baseline, no significant difference was noted in serum vitamin $D$ levels among the groups ( $p>0.05$ ) (Table 1).

Baseline BMI, FFM and percent fat measurements did not significantly differ among the study groups, and no significant differences were noted between groups I and II regarding isokinetic measurements ( $p>$.05). Chair stand and grip strength test scores were higher in group I than in groups II and III and arm curl test scores were higher in the group I when compared with those in group the III and in group the II when compared with those in the group III $(p<.05)$. No significant differences were noted between groups II and III for the chair stand and grip strength tests or between groups I and II for the arm curl test ( $p>$.05). Furthermore, extension torque and power at $60^{\circ} \cdot \mathrm{s}^{-1}$ and $180^{\circ} \cdot \mathrm{s}^{-1}$ and flexion torque at $60^{\circ} \cdot \mathrm{s}^{-1}$ were higher in the group I than in the group III $(p<.05)$. The flexion torque and power at $60^{\circ} \cdot \mathrm{s}^{-1}$ and extension torque at $60^{\circ} \cdot \mathrm{s}^{-1}$ were higher in the group II than in the group III $(p<.05)$ (Table 1).

According to the $25(\mathrm{OH}) \mathrm{D}$ blood concentrations at the end of the study, $70 \%$ and $71 \%$ of women in groups I and II, respectively, reached levels $>30 \mathrm{ng} / \mathrm{mL}$, whereas only $37 \%$ of the women in group III reached these levels. Repeated measures of ANOVA revealed a significant time effect for 25(OH)D levels $(p<.025)$, while no group effect was noted ( $p>$.025) (Table 1). 


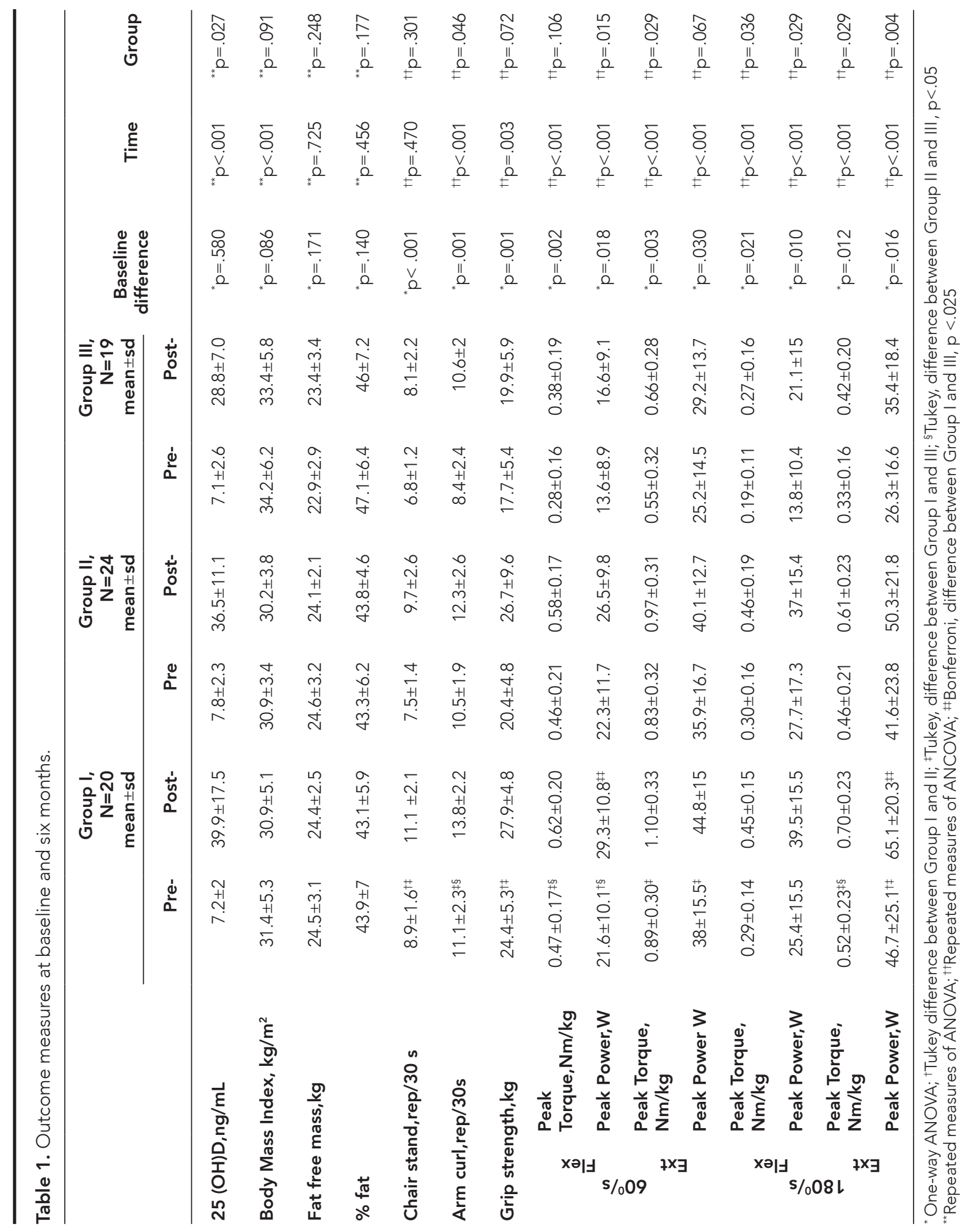


There were no significant time effect for the FFM and percent fat values ( $p>$.025) but did so for BMI $(p<.025)$. No significant group effects were noted for BMI, FFM and percent fat values ( $p>$.025) (Table 1).

There was no significant time effect for the chair stand test ( $p>$.025), whereas significant time effects were noted for grip strength, arm curl, flexor and extensor torque and power at $60^{\circ} \cdot \mathrm{s}^{-1}$ and $180^{\circ} \cdot \mathrm{s}^{-1}$ for all groups $(p<.025)$. The performance of flexor power at $60^{\circ} \cdot \mathrm{s}^{-1}$ and that for extensor power at $180^{\circ} \cdot \mathrm{s}^{-1}$ were higher in group I than in group III ( $p<.025)$ (Table 1).

\section{DISCUSSION}

The results in this study demonstrated that vitamin D supplementation improved BMl, arm curl, grip strength as well as flexor, extensor torque, and power at $60^{\circ} \cdot \mathrm{s}^{-1}$ and $180^{\circ} \cdot \mathrm{s}^{-1}$ in all age groups. The effect sizes for flexion power at $60^{\circ} \cdot \mathrm{s}^{-1}$ and extension power at $180^{\circ} \cdot \mathrm{s}^{-1}$ were greater in group 1 than in the group 3.

At baseline, 25(OH)D levels were $<15 \mathrm{ng} / \mathrm{mL}$ (range 4-14 $\mathrm{ng} / \mathrm{mL}$ ) in all groups without any significant differences. Chair stand and grip strength were higher in group I than in groups II and III, while arm curl was lower in group III than in groups I and II. Flexor and extensor torque at $60^{\circ} \cdot \mathrm{s}^{-1}$ were significantly lower in group III than in groups I and II. Extensor power at $60^{\circ} \cdot \mathrm{s}^{-1}$ and $180^{\circ} \cdot \mathrm{s}^{-1}$ and extensor torque at $180^{\circ} \cdot \mathrm{s}^{-1}$ were significantly lower in group III than in group I, while flexion power at $60^{\circ} \cdot \mathrm{s}^{-1}$ and $180^{\circ} \cdot \mathrm{s}^{-1}$ and also flexion torque at $180^{\circ} \cdot \mathrm{s}^{-1}$ were significantly lower in group III than in group II. These findings suggested that muscle strength and power correlated with age rather than with vitamin $D$ levels.

Grip strength was lower than normative values in all groups at baseline (19). Conflicting results have been reported regarding the relation between vitamin $\mathrm{D}$ and grip strength, with some studies proposing the presence of such a relation $(6,7,11)$ while others proposing the lack of a relation (12). A study reported that women with serum vitamin $D$ levels $<30 \mathrm{ng} / \mathrm{mL}$ had lower grip strength (11), while another study reported that grip strength was lower when serum vitamin $D$ levels were $<20 \mathrm{ng} / \mathrm{mL}$ in both sexes (6). In addition, various cut-off levels were defined for serum vitamin $25(\mathrm{OH}) \mathrm{D}$ levels in studies investigating the relation between the physical performance of lower extremities. In some studies, physical performance was reportedly lower at vitamin 25(OH)D levels $<10 \mathrm{ng} / \mathrm{mL}$ (6), while other studies proposed different levels such as $<32 \mathrm{ng} / \mathrm{mL}(20)$ and $<30 \mathrm{ng} / \mathrm{mL}(11,13)$. In a study on individuals older than 60 years of age (51 women, 75\% physically active), lower extremity performances were suggested to be worse when serum 25(OH)D concentrations were between 9 and $16 \mathrm{ng} / \mathrm{mL}$ (5). In the present study, we could not determine whether group differences in muscle strength, muscle power and physical performances were associated with age or serum vitamin D levels because none of the participants had normal vitamin $D$ levels.

Although it has been reported that there was no significant effect of vitamin $D$ on muscle power $(2,11,14)$, Bischoof et al.(20) stated that there was a significant, positive correlation between muscle power and 25(OH)D only in male participants between 65 and 95 years of age. In another study, vitamin $D$ was positively associated with isometric flexion and extension average torque at the knee and isokinetic flexion strength at $60^{\circ} \cdot \mathrm{s}^{-1}$ and $180^{\circ} \cdot \mathrm{s}^{-1}$; there was no correlation between vitamin $\mathrm{D}$ and knee isokinetic extension strength at $60^{\circ} \cdot \mathrm{s}^{-1}$ and $180^{\circ} \cdot \mathrm{s}^{-1}$ (12). Previous studies have suggested that vitamin $D$ affected isometric muscle strength (7-11) and isokinetic muscle strength $(7,12,13)$, but other reports have proposed no effect $(12,14-17)$. In this study, improvement was observed in the knee flexor as well as extensor torque and power at $60^{\circ} \cdot \mathrm{s}^{-1}$ and $180^{\circ} \cdot \mathrm{s}^{-1}$ in all assessed age groups, and the between-group effect sizes for flexion power at $60^{\circ} \cdot \mathrm{s}^{-1}$ and extension power at $180^{\circ} \cdot \mathrm{s}^{-1}$ after vitamin $\mathrm{D}$ supplementation suggested that vitamin $D$ was more effective for muscle power in younger age groups than in older ones. This outcome suggested that the effect of vitamin $D$ supplementation depends on age and also on increased 25(OH)D levels because 25(OH)D levels were $>30 \mathrm{ng} / \mathrm{mL}$ in $70 \%$ of participants in the group I and in $37 \%$ of participants in group III. Serum $25(\mathrm{OH})$ 
D level increment was $481 \%$ in group I, 404\% in group II and 360\% in group III. Grip strength increased from $15 \%$ at baseline to $50 \%$ in group I, from $13 \%$ to $35 \%$ in group II and from $11 \%$ to $21 \%$ in group III. The increase in grip strength was consistent with the increase in serum vitamin $\mathrm{D}$ levels. It has been demonstrated that the greatest improvement of muscle strength occurred from very low concentrations of serum 25(OH)D up to $16-20 \mathrm{ng} / \mathrm{mL}$ (5).

Even though vitamin $D$ supplementation resulted in increased grip strength and isokinetic strength in our study, it had no effect on chair stand test performance. However, McCarthy et al.(21) stated that isokinetic knee extensor strength was an important but moderate predictor of chair stand test performance and additional independent variables such as leg power, leg endurance, posture, and psychological variables may have contributed to the variance in chair stand test performance.

Obesity is a major risk factor for vitamin $D$ deficiency because of body fat absorption of vitamin D $(11,22)$. BMI and higher body fat percentage are significantly associated with lower serum $25(\mathrm{OH})$ $\mathrm{D}$ levels, especially in older persons, and there is a relation between vitamin $D$ levels and adipose tissue (23). On the basis of this evidence, obese individuals are expected to require higher doses of vitamin D supplementation (22). The smaller increment of serum 25(OH)D levels in the group III depended on the percentage of obese participants in this age group. BMI was $>30 \mathrm{~kg} / \mathrm{m}^{2}$ in $54 \%$ of the group I, $60 \%$ of the group II and $79 \%$ of the group III in this study.

Although high doses of vitamin D were used in this study, there were no adverse reactions. In a

\section{REFERENCES}

1. Araghi SO, van Dijk SC, Ham AC, et al. BMI and body fat mass is inversely associated with vitamin $D$ levels in older individuals. J Nutr Health Aging 2015;19(10):980-5. (PMID:26624208).

2. Beaudart C, Buckinx F, Rabenda V, et al. The effects of vitamin $D$ on muscle strength, muscle mass and muscle power: a systematic review and meta-analysis of randomised controlled trials. J Clin Endocrinol Metab 2014;99(11):4335-45. (PMID:25033068). previous review, it was suggested that doses $<300.000$ IU do not provide an adequate amount of vitamin $D$ for restoring vitamin $D$ status in most populations, and the increases in $25(\mathrm{OH}) \mathrm{D}$ concentration safely occur in a majority of individuals (24). Moreover, this review highlighted previous works wherein there were no adverse events when participants received up to 500.000 IU of vitamin D (24).

One of the limitations of the present study was its small sample size. In addition, there was a significant difference in muscle strength, especially for isokinetic muscle strength, between groups at baseline. Furthermore, the lack of a control group with different serum vitamin $D$ levels is another study limitation. In addition, we did not have specific information regarding sunlight exposure. Lastly, we were unable to evaluate the response of muscle strength of different body regions to vitamin $\mathrm{D}$ supplementation. Randomised, controlled studies using a large sample of participants with different serum 25(OH)D levels are required for defining optimal treatment modalities, including the dose and mode of administration and duration. Future research may also identify factors such as age, sex, physical activity level, the number of concomitant medications and endogenous gonadal hormone levels that affect responses to vitamin $D$ supplementation.

\section{ACKNOWLEDGEMENTS}

We are grateful to associate professor Ayşenur Yeğin for assisting with data analysis, and to physiotherapist Emir Koç for his assistance in performing test measurements.

3. Bischoff HA, Stahelin HB, Urscheler N, et al. Muscle strength in the elderly: its relation to vitamin $D$ metabolites. Arch Phys Med Rehab 1999;80(1):54-8. (PMID:9915372).

4. Bischoff-Ferrari H, Dietrich T, Orav E, et al. Higher 25-hydroxyvitamin D concentration are associated with better lower-extremity function in both active and inactive persons aged $>60 \mathrm{y}$. Am J Clin Nutr 2004;80(3):752-8. (PMID:15321818). 
5. Bohannon RW, Peolsson A, Westropp N, Desrosiers J, Bear-Lehman J. Reference values for adult grip strength measured with a Jamar dynamometer: a descriptive meta-analysis. Physiotherapy 2006;92(1):11-15.

6. Dhesi JK, Jackson SH, Bearne LM, et al. Vitamin D supplementation improves neuromuscular function in older people who fall. Age Ageing 2004;33(6):58995. (PMID:15501836).

7. Grimaldi AS, Parker BA, Capizzi JA, et al. $25(\mathrm{OH})$ vitamin $D$ is associated with greater muscle strength in healthy men and women. Med Sci Sports Exerc 2013;45(1):157-62. (PMID:28696084).

8. Grimnes G, Emaus N, Cashman KD, Jorde R. The effect of high-dose vitamin $D$ supplementation on muscular function and quality of life in postmenopausal women-a randomized controlled trial. Clin Endocrinol (Oxf) 2017;87(1):20-8. (PMID:28423480).

9. Gupta R, Sharma U, Gupta N, et al. Effect of cholecalciferol and calcium supplementation on muscle strength and energy metabolism in vitamin D deficient Asian Indians: a randomized controlled trial. Clin Endocrinol 2010;73(4):445-51. (PMID:20455886).

10. Houston DK, Cesari M, Ferrucci L, et al. Association between vitamin $\mathrm{D}$ status and physical performance: the InCHIANTI study. J Gerontol A Biol Sci Med Sci 2007;62(4):440-6. (PMID:17452740).

11. Iolascon G, Mauro GL, Fiore $P$, et al. Can vitamin D deficiency influence muscle performance in postmenopausal women? A multicenter retrospective study. Eur J Phys Rehab Med 2018;54(5):676-82. (PMID:28696084).

12. Janssen HC, Samson MM, Verhaar HJ. Muscle strength and mobility in vitamin D-insufficient female geriatric patients: a randomized controlled trial on vitamin D and calcium supplementation. Aging Clin Exp Res 2010;22:78-84. (PMID:20305368).

13. Kara M, Ekiz T, Kara Ö, et al. does vitamin D affect muscle strength and architecture? An isokinetic and ultrasonographic study. Asia Pac J Clin Nutr 2017;26(1):85-8. (PMID:28049266).

14. Kearns M, Alvarez J, Tangpricha V. Large, singledose, oral vitamin D supplementation in adult populations: a systematic review. Endocr Pract 2013;20(4):341-51. (PMID:24246341).
15. Keller K, Engelhardt M. Strength and muscle mass loss with aging process. Age and strength loss. Muscles Ligaments Tendons J 2014;3(4):346-50. (PMID:24596700).

16. McCarthy EK, Horvat MA, Holtsberg PA, Wisenbaker JM. Repeated chair stands as a measure of lower limb strength in sexagenarian women. J Gerontol A Biol Sci Med Sci 2004; 59(11):1207-12. (PMID:15602077).

17. Moreira-Pfrimer LD, Pedrosa MA, Teixeira L, LazarettiCastro M. Treatment of vitamin D deficiency increases lower limb muscle strength in institutionalized older people independently of regular physical activity: a randomized double-blind controlled trial. Ann Nutr Metab 2009;54(4):291-300. (PMID:19729890).

18. Pfeifer $M$, Begerow $B$, Minne HW, Suppan $K$, Fahrleitner-Pammer A, Dobnig $H$. Effects of a long-term vitamin $D$ and calcium supplementation on falls and parameters of muscle function in community-dwelling older individuals. Osteoporos Int 2009;20:315-22. (PMID:18629569).

19. Pioli G, Giusti $A$. The inconsistent data on the effect of vitamin D on muscle function. J Spine 2012;1:e107.

20. Rikli RE, Jones CJ. Functional fitness normative scores for community-residing older adults, ages 60-94. J Aging Phys Activ 1999;7:162-81.

21. Smedshaug GB, Pedersen JI, Meyer HE. Can vitamin D supplementation improve grip strength in elderly nursing home residents? A double-blinded controlled trial. Scand J Food Nutr 2007;51:74-8. (PMCID:PMC2607001).

22. Stockton KA, Mengersen K, Paratz JD, Kandiah D, Bennell KL. Effect of vitamin D supplementation on muscle strength:a systematic review and meta-analysis. Osteoporos Int 2011;22(3):859-71. (PMID:20924748).

23. Wortsman J, Matsuoka LY, Chen TC, Lu Z, Holick MF. Decreased biovailability of vitamin D in obesity. Am J Clin Nutr 2000;72:690-3. (PMID:10966885).

24. Zhu K, Austin N, Devine A, Brcue D, Prince RL. A randomized controlled trial of the effects of vitamin $D$ on muscle strength and mobility in older women with vitamin D insufficiency. J Am Geriatr Soc 2010;58:2063-8. (PMID:21054285). 